\title{
IMMUNOHISTOCHEMISTRY WITH MONOCLONAL ANTIBODIES HER2/NEU PREDICTS SURVIVAL IN BREAST CANCER NATIVE PERUVIAN PATIENTS
}

\author{
Renzo Gamarra Manrique ${ }^{1}$ \\ ${ }^{1}$ Universidad Nacional de San Agustin de Arequipa
}

June 24, 2020

\begin{abstract}
Breast cancer is a heterogeneous pathology. There are subgroups with different molecular characteristics, and they must be identified to direct the therapy and to have a clear prognosis. HER2/neu (human epidermal growth receptor factor $2 /$ neuro glioblastoma derived oncogene homolog) receptor overexpression is a characteristic that must be evaluated in each population. We apply the monoclonal antibody technique in the indigenous population of Peru, we also correlate the presence of the receptor with global survival. It's an experimental, prospective and analytical study. Twenty three samples were evaluated, obtained from patients with adenocarcinoma of the breast. The HER2/neu expression was determined by immunohistochemical technique (monoclonal antibodies). The results were verified 10 cases were positive for overexpression (43.47\%). The negative cases were $13(56.52 \%)$. The overall survival at 3 years was $69.90 \%$ for the Her $2 /$ neu positive and $85.00 \%$ for negative, showed statistically significant differences $(\mathrm{p}=0.017)$. Finally, it was feasible to apply the monoclonal antibody technique and to statistically correlate HER2/neu overexpression with TNM clinical stage, predicting less survival when present. Applying an immunohistochemical technique is feasible in native Peruvian women. The main benefit is to apply biological therapy with monoclonal antibodies, according to their molecular profile.
\end{abstract}

\section{Hosted file}

Research Article.pdf available at https://authorea.com/users/336597/articles/462252immunohistochemistry-with-monoclonal-antibodies-her2-neu-predicts-survival-in-breastcancer-native-peruvian-patients 